\title{
Chamada para próxima submissão
}

A Revista Memória em Rede, periódico eletrônico semestral publicado pelo Programa de Pós-Graduação em Memória Social e Patrimônio Cultural do Instituto de Ciências Humanas da Universidade Federal de Pelotas, ISSN 2177-4129, estará recebendo inscrição de contribuições para as sessões artigos, ensaios, ensaios visuais, resenhas de livros para o número 19 de 2018. Podem submeter propostas mestres e doutores. As propostas inscritas serão avaliadas pela avaliação cega dos pares e pelo Conselho Editorial da revista, se aprovadas, serão incluídas no referido número a ser publicado em julho de 2018. Data limite para recebimento das propostas: 15 de maio de 2018 Data limite para publicação: 31 de julho de 2018. Maiores informações sobre a revista e normas de publicação podem ser encontradas em:

https://periodicos.ufpel.edu.br/ojs2/index.php/Memoria/index

\section{Dossiê:}

\section{Memória, patrimônio e imagem}

Eduardo Roberto Jordão Knack

Rita Juliana Soares Poloni

As imagens estão presentes em todas as sociedades, em diferentes espaços e em diferentes períodos da história da humanidade. "As imagens pertencem ao universo dos vestígios mais antigos da vida humana que chegaram até nossos dias." (KNAUSS, 2006, p.98). Tanto imagens bidimensionais como tridimensionais estão associadas com a própria experiência humana da vida social. E a produção de imagens não pode ser compreendia sem uma reflexão sobre a memória.

Muitas imagens tridimensionais, como esculturas, obeliscos, estátuas funerárias, entre outras, são construídas com objetivo memorial claro, bem como bidimensionais (retratos, pinturas, fotografias). A paisagem, como Simmel (2013, p.89) indica, é uma unidade recortada de um campo visual amplo, implicando operações de seleção que estão impregnadas pela cultura e subjetividade de quem olha, portanto, também está intimamente relacionada com a memória.

Refletir sobre essas relações é fundamental para compreender um aspecto importante das sociedades contemporâneas: a incessante e compulsiva busca pela memória. Candau (2013, p.103) fala em "mnemotropismo" generalizado, que pode ser 
observado em toda parte, "e por vezes até à saturação, manifestam-se os sinais de uma inflação de memória, de uma febre comemorativa e de um produtivismo arquivístico". Huyssen (2007) também menciona uma obsessão pela memória nos debates públicos e a influência da mídia nessa busca memorial, o que também remete ao papel da imagem: a televisão, o cinema, a internet como meios difusores não apenas de imagens articuladas à memória, mas da própria necessidade memorial e do medo do esquecimento.

A circularidade das imagens, seus suportes e espaços também são elementos essenciais para uma reflexão aprofundada sobre possíveis relações com a memória e com o patrimônio. Como Meneses (2003, p.28) chama atenção, é fundamental "percorrer o ciclo completo de sua produção, circulação e consumo", pois as imagens "não têm sentido em si, imanentes." Portanto, além de compreender os diferentes tipos de imagens descritos acima, em sua relação com a memória, também é imperativo observar o circuito social dessas imagens, sua forma de produção e consumo, os regimes visuais aos quais estão submetidas, entendidos como formas de construção e de recepção do olhar, a interação entre observador e o objeto observado.

Memória e imagem estão intrinsecamente relacionadas. Diferentes perspectivas metodológicas reconhecem essa relação. Bergson, com sua fenomenologia da lembrança, vincula à memória a capacidade da percepção de captar estímulos que recebemos do mundo exterior, possibilitando sua devolução por intermédio da ação: "a percepção aparece como um intervalo entre ações e reações do organismo; algo como um 'vazio' que se povoa de imagens as quais, trabalhadas, assumirão a qualidade de signos da consciência." (BOSI, 1994, p.44-45).

Halbwachs (2006, p.30) pautou suas reflexões sobre a memória dentro do contexto social, partindo do princípio de que "nossas lembranças permanecem coletivas e nos são lembradas por outros, ainda que se trate de eventos em que somente nós estivemos envolvidos e objetos que somente nós vimos." O autor dos "quadros sociais da memória" também reconheceu o papel que a imagem tem na rememoração.

Seu exemplo marcante nesse aspecto é sobre a caminhada em uma cidade desconhecida, em que nossas lembranças de seus espaços não se formam solitariamente, uma vez que outros relatos, mapas e/ou imagens contribuem para construção da memória, pois "é comum que imagens desse tipo, impostas pelo meio em que vivemos, modifiquem a impressão que guardamos de um fato antigo, de uma pessoa outrora conhecida" (HALBWACHS, 2006, p.30), ou mesmo das ruas, praças, casas e edifícios de uma cidade antes desconhecida pelo visitante. 
Ricoeur (2007) também reconhece a importância de se debater aproximações (e distanciamentos) entre memória e imagem, rememoração e imaginação. Em seu conhecido livro "A memória, a história, o esquecimento", seu capítulo inicial é dedicado ao debate entre memória e imaginação, reconhecendo que a presença da lembrança "aparenta ser mesmo de uma imagem", que pode ser visual ou auditiva (acrescentaríamos olfativa), no entanto, constituindo duas intencionalidades diferentes, uma voltada para o fantástico, utópico (ou distópico), e a outra voltada para anterioridade carregada pela marca temporal da "coisa lembrada". (RICOEUR, 2007, p.25-26).

As imagens são fundamentais para uma mobilização da memória pelos grupos sociais e pela "transmissão memorial" em seu seio, funcionam, como diria Candau (2012), como "sociotransmissores". De fato, essa exteriorização da memória está associada a necessidade de produzir traços que remontam aos primórdios das sociedades humanas com as pinturas rupestres, necessidade que acompanhou 0 desenrolar da história das sociedades humanas, adentrando o mundo contemporâneo em uma escala nunca antes imaginada: "a exteriorização da memória que se exprime por uma profusão de imagens (difundidas continuamente, tratadas, estocadas) e que eu qualifico como iconorreia." (CANDAU, 2012, p.111).

Essa "iconorreia", essa saturação de imagens com uma carga memorial, é caracterizada pelo exponencial aumento de sua difusão atual, o que paradoxalmente torna sua transmissão mais difícil, pois atrapalha a compreensão do suporte memorial vinculado à imagem. Esse quadro de inflação memorial, de saturação imagética, afeta também formas de concepção do patrimônio. Poulot (2011, p.14-15), observa que o "propósito patrimonial" esteve vinculado, desde o Renascimento, com a "representação de uma herança cultural" que "foi se imprimindo, pouco a pouco, nos guias, nos relatos de viagem, nas correspondências, nos jornais e nos catálogos", ou seja, uma exaltação do valor histórico e artístico dessas obras nesses suportes que carregavam imagens destinadas ao estudo e apreciação de uma pequena parcela da sociedade.

No mundo contemporâneo a categoria "patrimônio" assume um caráter polissêmico, com vários usos, empregada indiscriminadamente por uma variada parcela de grupos e sujeitos, com diferentes finalidades e objetivos. Isso afetou a função da imagem (em sua relação íntima com a memória) para pensar e representar o patrimônio. Além disso, a explosão da mídia (e uma consequente explosão de suportes imagéticos) também contribuiu para uma transformação significativa da imagem e dos usos da imagem do patrimônio nas últimas décadas, inserindo bens 
patrimoniais locais em uma escala de fenômenos globais, e vice-versa. Esses são alguns pontos que o presente dossiê procura abordar, partindo de diferentes concepções teóricas sobre memória e patrimônio, articulados com o papel da imagem nas sociedades contemporâneas.

\section{Referências}

BOSI, Ecléa. Memória e sociedade: lembranças dos velhos. 3.Ed. São Paulo: Companhia das Letras, 1994.

CANDAU, Joël. Memória e identidade. São Paulo: Contexto, 2012.

CANDAU, Joël. Antropologia da memória. Lisboa: Instituto Piaget, 2013.

HUYSSEN, Andreas. En busca del futuro perdido: cultura y memoria en tiempos de globalización. Buenos Aires: Fondo de Cultura Económica de Argentina, 2007.

HALBWACHS, Maurice. A memória coletiva. São Paulo: Centauro, 2006.

KNAUSS, Paulo. O desafio de fazer História com imagens: arte e cultura visual. In: ArtCultura, Uberlândia, v.8, n.12, 2006.

MENESES, Ulpiano T. Bezerra de. Fontes visuais, cultura visual, História Visual. Balanço provisório, propostas cautelares. In: Revista Brasileira de História, São Paulo, v.23, n.45, 2003.

POULOT, Dominique. O modelo republicano de museu e sua tradição. In: BORGES, Maria Eliza Linhares. (org.). Inovações, coleções, museus. Belo Horizonte: Autêntica Editora, 2011.

RICOEUR, Paul. A memória, a história, o esquecimento. Campinas: Editora da Unicamp, 2007.

SIMMEL, Georg. Filosofía del paisaje. Madrid: Casimiro, 2013. 